\title{
THE EFFECT OF MAN-MADE PLATFORMS ON OSPREY REPRODUCTION AT LOON LAKE, SASKATCHEWAN
}

\author{
C. Stuart Houston \\ 863 University Drive, Saskatoon, SK, Canada S7N 0J8
}

\author{
Frank ScOTT \\ $R R \# 3$, Saskatoon, SK, Canada S7K $3 S 6$
}

\begin{abstract}
Since 1975 we have banded 277 nestling Ospreys at 138 successful nests near Loon Lake, Saskatchewan. There were 137 failed nesting attempts, in total yielding a production of 277 young from 275 attempts (1.0 young per active nest). Since 1986, over half (37 of 64) of successful nests have been on man-made platforms. Pairs on platforms had a success rate of $62.9 \%$ and raised 2.1 young per successful nest, compared with a success rate of $45.9 \%$ and 2.0 young per successful nest in osprey-built nests in trees.

Alpha-numeric color bands have been added since 1988 to all nestlings and to 22 adults, including five males. Only one of the trapped adults had been banded as a nestling at Loon Lake; most others are presumed to have immigrated from elsewhere. There have been eight retrappings of six adults in subsequent years.

From 299 Loon Lake Ospreys and 14 from seven other Saskatchewan lakes, 12 recoveries to date include 2 from Colombia and 1 each from Ecuador, Panama, Costa Rica, Vera Cruz, Louisiana and New Mexico.
\end{abstract}

Efecto de las plataformas hechas por el hombre, en la reproducción de Äguila Pescadora, en Loon Lake, Saskatchewan

Extracto.-Desde 1975 hemos anillado 277 Ảguilas Pescadoras, recién salidas de 138 nidos logrados, cerca de Loon Lake, Saskatchewan. Hubieron 137 intentos de anidar fallidos, dando en total una producción de 277 jóvenes provenientes de 275 intentos (1.0 cría por nido activo). Desde 1986, más de la mitad (37 de 64) de nidos con éxito han sido ubicados en plataformas hechas a mano. Las parejas que anidaron en estas plataformas tuvieron éxito en el $62.9 \%$ de los casos, y criaron 2.1 crías por nido logrado; comparado con el porcentaje de logros en nidos construídos en árboles por estas Pandion haliaetus, que fue de $45.9 \%$ y 2.0 crías por nido.

Desde 1988, anillos alfa-numerados coloreados han sido añadidos a todos los jóvenes, y a 22 adultos incluyendo cinco machos. Solo uno de los adultos atrapados ha sido anillado, como procedente de un nido de Loon Lake; la mayor parte de los otros se presume que han inmigrado de otro lugar. Seis adultos han sido racapturados ocho veces en años subsecuentes.

De 299 Águilas Pescadoras de Loon Lake, y 14 más de esta especie procedentes de otros siete lagos de Saskatchewan, hasta la fecha, 12 recuperaciones incluyen dos de Colombia y una de cada uno de los siguientes lugares: Ecuador, Panamá, Costa Rica, Veracruz, Louisiana y Nuevo México.

[Traducción de Eudoxio Paredes-Ruiz]

The association of CSH with Fran and "Hammy" Hamerstrom extends back to the meeting of the American Ornithologists' Union in Regina, Saskatchewan, in August 1959. Fran had obtained banding permits for all the states and provinces between Wisconsin and Saskatchewan. She and Hammy had cages of live pigeons and starlings on top of their station wagon and numerous sizes of bal-chatri traps. My wife, Mary, and $I$ were entranced but our reaction paled beside that of our teenage friends and assistants, Glen Fox, Gary An- weiler and Spencer Sealy. The boys spent a lot of time with Fran at the meeting, learning the bal-chatri technique from the expert herself. Soon after we returned to Yorkton from Regina, Gary demonstrated the effectiveness of the bal-chatri in catching kestrels in fall migration. Glen Fox in 1960 and Gary Anweiler and Ross Lein in 1961 went to Plainfield as "gabboons."

I have been in correspondence with Fran ever since. We have met every few years at meetings of the American Ornithologists' Union or Raptor Research Foun- 
dation as well as at one International Congress of Ornithology at Oxford in 1966. Without fail, we get together to discuss our recent experiences with raptors. Fran is a most encouraging person, one of the few who writes spontaneous and unsolicited compliments concerning a published paper. She was especially impressed by my owl banding efforts and shared widely with others my paper "The Year of the Owls" in 1960.

When Fran discusses a paper or asks a question at a meeting, she brings broad experience from a lifetime in the field. At the Inland Bird Banding Association at Rapid City, South Dakota, in 1987, she gave an impressive, reasoned rebuttal to counter the "pro-enforcement" video shown there concerning the raptor "sting" operation.

Mary and I have read each of her books with interest. We often read a chapter from "Walk When the Moon is Full," our favorite, to our grandchildren. Fran tells me that each one of her books has been someone's favorite, a tribute to her wide readership and the variety of topics she has written about.

The search for nests of the Osprey (Pandion haliaetus) in the southern edge of the boreal forest in west-central Saskatchewan began in earnest in 1975 (Scott and Surkan 1976), during weekly trips by FS by air from Loon Lake village to a clinic on the Ministikwan Indian Reserve, part of his medical practice between 1962 and 1991. This search was stimulated in part by a keen appreciation of the plight of the Osprey in his homeland, the United Kingdom. Our study of Osprey densities and productivity has caused us to make increased use of artificial platforms.

\section{Study Area AND Methods}

The area studied extends $45 \mathrm{~km}$ west, $15 \mathrm{~km}$ north and $20 \mathrm{~km}$ south of the village of Loon Lake (Fig. 1). Each year three aerial surveys were made, using a Piper PA 18 150 equipped with floats. The first, in May, recorded occupied nests with incubating adults. A second flight in early June identified those nests containing eggs, which were easy to see and count from the air once the adult left the nest. During a final flight in July we determined which occupied nests had been successful and attempted to assess which trees were climbable. Because the young lay flat in the nest and blended well with lining material and fish remains, they were extremely difficult to count. At all times, watch was kept for possible new nests in the forest near lakes and ponds. Most nests were within $100 \mathrm{~m}$ of shore and provided the occupants a view of the water, though rarely a nest was up to $2 \mathrm{~km}$ from water.

Over 16 years, we have spent 16 weekends in July banding nestlings, 10 weekends in March putting up nest platforms, and 3 weekends in early June trapping adults on their nests with noose carpets. Weather has been favorable on every occasion. This effort has included a minimum of $160 \mathrm{hr}$ of air time and $20000 \mathrm{~km}$ by car, without counting horizontal distance by canoe, motorboat and skidoo and vertical distance climbing up $23 \mathrm{~m}$ trees. Up to six helpers volunteered their time and equipment on each occasion. If cost-accounted, the labor bill would be prodigious except that the work is too dangerous-no one would do it for money!

Construction of Nest Platforms. Since bulky, heavy nests at the top of dead trees are hazardous both to Ospreys and banders (in Florida, 50 to $70 \%$ of trees blew down each year; Poole 1989), we decided to construct nest platforms similar to those used in the eastern part of this continent. In Michigan, Postupalsky and Stackpole (1974) found that use of man-made platforms reduced nestling mortality from $28 \%$ to $7 \%$, mainly by eliminating blowdowns of nest trees. In Michigan, Florida, Maryland, New York and Idaho, up to twice as many young per occupied nest were raised on platform nests as compared to tree nests (Poole 1989).

Of our first three platforms, built in March 1978, only one was close enough to allow transfer of nest material from the adjacent dead tree we pushed down by hand This platform was used that season but successfully raised young only that time, with five subsequent failures.

Platform building resumed in March 1983, when three platforms were constructed. Only the one containing Osprey nest material from a nearby dead tree was used by Ospreys. Beginning in 1984, platforms were constructed each March (1991 excepted). Since 1986 we have bullt each platform in a live tree next to the previously used dead tree, except in 1990, when no live tree was nearby; on this occasion we transported an $8 \mathrm{~m}$ high windmill frame from a deserted farm $300 \mathrm{~km}$ to the south and built a platform on it. Also since 1986 we have transferred most of the previous nest structure, fashioning a central cup lined with Osprey down and fish scales from the natural nest. All platforms had a frame of $5 \times 15 \mathrm{~cm}$ lumber, supported by angle braces of the same size (Scott and Houston 1985). Attachment to the tree stump with 0.95 $\mathrm{cm}$ lag bolts proved inadequate as in three instances the lag bolts broke during windstorms, causing the platform to collapse. Since 1990 we have used $1.27 \mathrm{~cm}$ lag bolts At first we used a sheet of plywood as a base but now we use cross-planks of $5 \times 10 \mathrm{~cm}$ lumber with gaps between allowing drainage. We were unable to collect accurate data concerning production in the 87 unsafe and unclimbable tree nest attempts.

\section{RESUlts AND Discussion}

Population Density. Until 1976, only sporadic pairs of breeding Ospreys had been recorded from 44 localities in Saskatchewan (Houston et al. 1977). Since then, the Loon Lake area has supported the highest reported density of breeding pairs in Canada between the Great Lakes and the Rocky Mountains. Each year there are from 20-27 breeding pairs, for an average of one pair per $65-80 \mathrm{~km}^{2}$ (Scott and Houston 1983). 


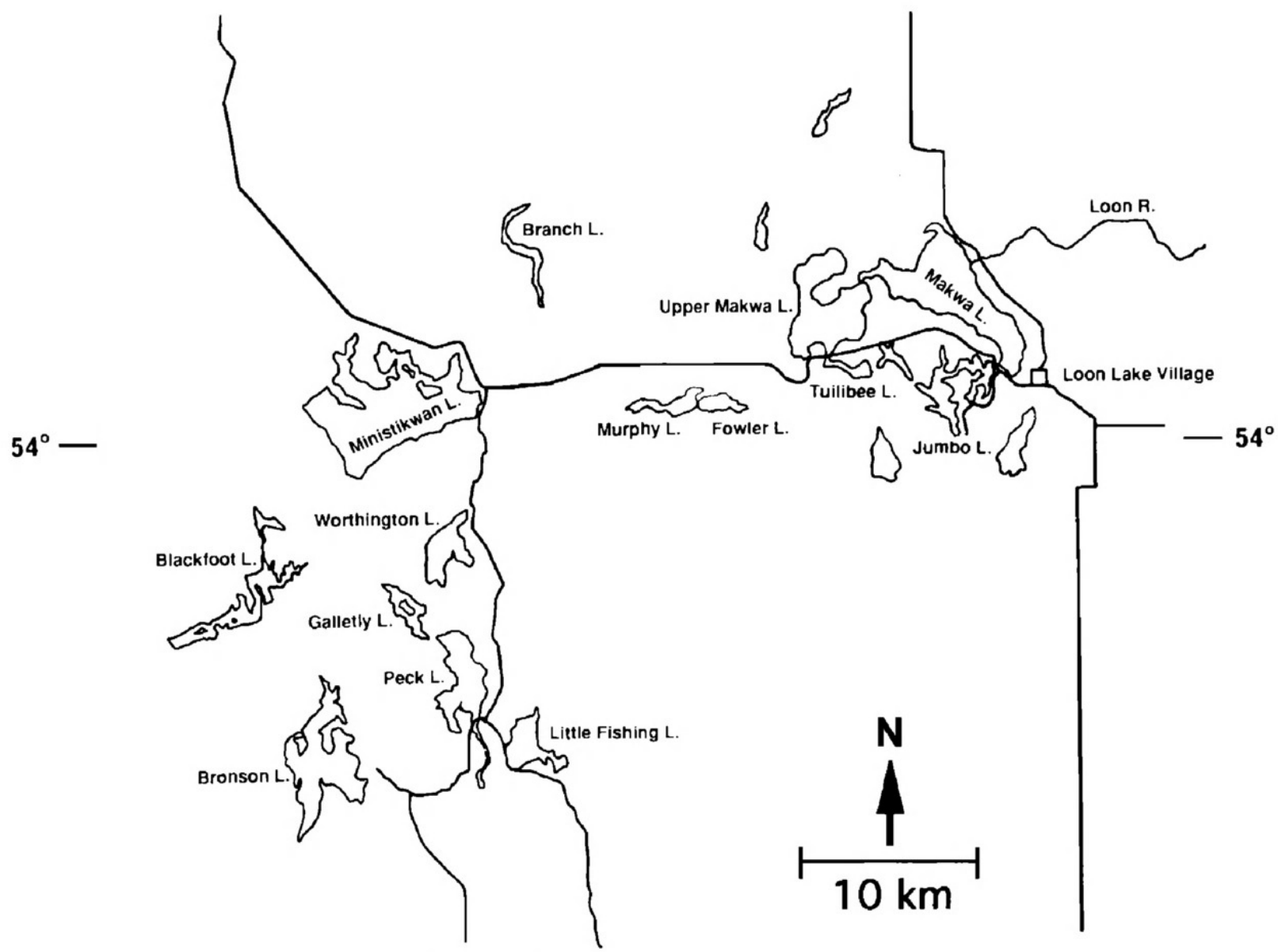

Figure 1. Map of the Loon Lake study area, Saskatchewan.

Breeding Success and Productivity. Between 1975 and 1991 there were 138 successful and 137 failed breeding attempts, producing 1.0 young per occupied nest and 2.0 young fledged per successful nest. This success was slightly lower than the 1.3 young per occupied and 2.1 per successful nest reported from Michigan (Postupalsky 1989). At Loon Lake, breeding success (Fig. 2, Table 1) varied appreciably among a) individual pairs, b) artificial nest structures and natural trees, and c) years.

Individual pairs. There were five instances of longterm breeding success and productivity far above the average; in each case Ospreys used an individual tree for many years. The two most productive nest sites were in live White Spruce (Picea glauca): at Branch Lake, 31 young fledged collectively in 14 of $16 \mathrm{yr}$; at Peck Lake, 21 young fledged in 12 of 17 yr. Next followed two uses of live Jackpine (Pinus banksiana): at Makwa Lake, where 16 young fledged in 7 of $8 \mathrm{yr}$ before the tree was abandoned and at the north shore of Peck Lake, where 12 young fledged in 6 of $10 \mathrm{yr}$ of occupancy. Ten young in 6 consecutive years were fledged from a dead Jackpine at Loon River before it was replaced with a platform.

The next four most successful uses of tree sites were at Ministikwan Lake, fledging nine young in 4 of $7 \mathrm{yr}$; at Makwa Lake, with nine young in 4 of $5 \mathrm{yr}$; at Little Fishing Lake with seven young in 3 of $5 \mathrm{yr}$ and Galletly Lake where seven young fledged in 3 of $5 \mathrm{yr}$.

In striking contrast, there have been 14 intermittently occupied tree sites which have produced only between one and six young during the entire study. Worse, a final 12 tree sites have produced no young, with failed attempts involving $8,5,4,3,3,2,1,1$, $1,1,1$ and $1 \mathrm{yr}$, respectively. Seven of these failed sites were at the two largest lakes, five at Ministikwan Lake and two at Bronson Lake. Of 24 tree nest sites that were deserted, all had failed to produce young in the final year (in 6 instances, the only year) of occupancy.

Artificial nest platforms. As in other parts of the 
Nestling Ospreys Banded at Loon Lake, Saskatchewan Number of Nests per Year

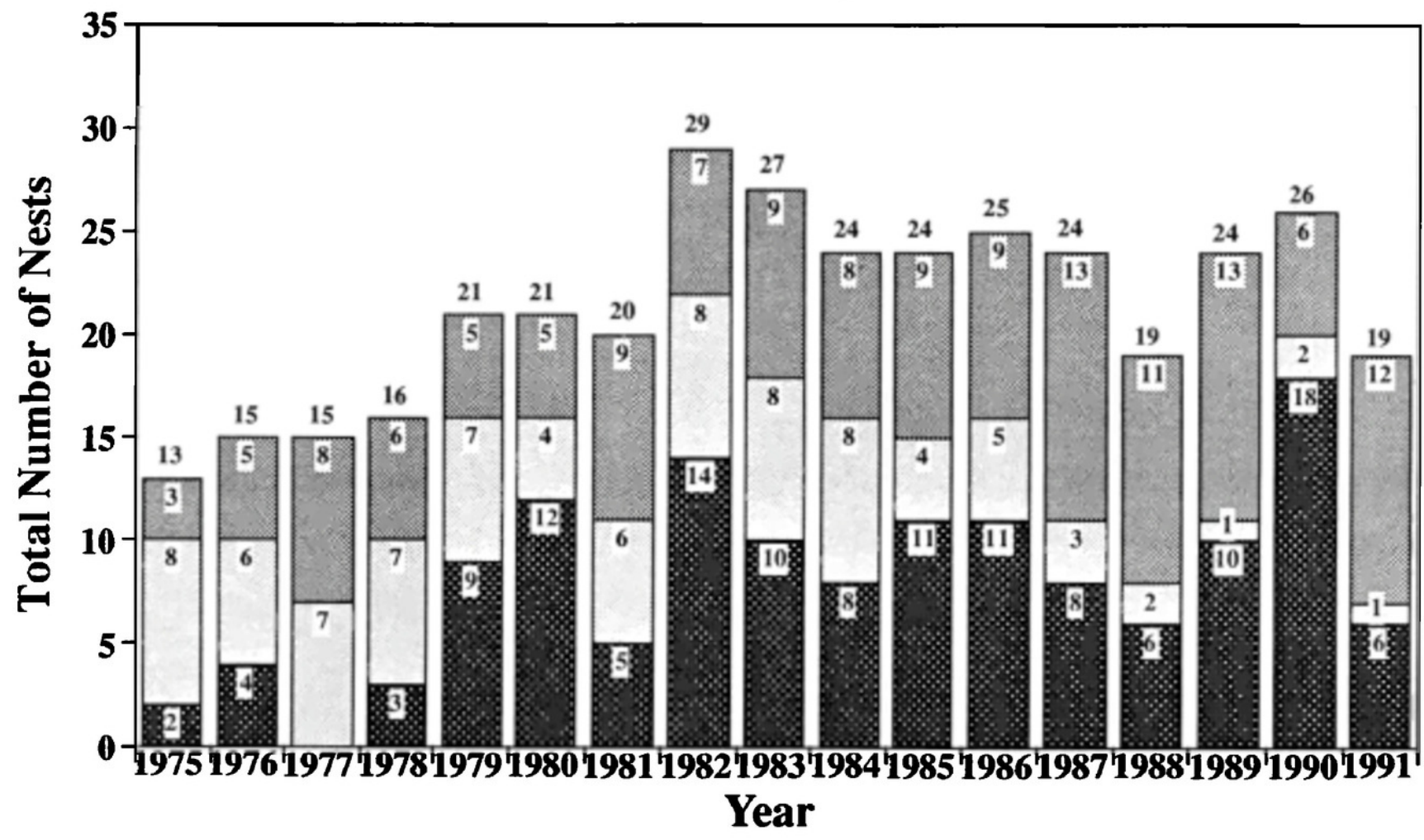

Failed Nests $\square$ Unsafe Nests $\square$ Successful Nests

Figure 2. Nestling Ospreys banded at Loon Lake, Saskatchewan, 1975-91.

Table 1. Productivity of Ospreys at Loon Lake, Saskatchewan, 1978-91.

\begin{tabular}{|c|c|c|c|c|c|}
\hline & \multicolumn{2}{|c|}{$1975-85$} & \multicolumn{2}{|c|}{$1986-91$} & \multirow[b]{2}{*}{$\begin{array}{c}\text { Total } \\
\text { ATTEMPTS }\end{array}$} \\
\hline & $\begin{array}{c}\text { NUMBER } \\
\text { ATTEMPTS }\end{array}$ & $\begin{array}{c}\text { YOUNG } \\
\text { BANDED }\end{array}$ & $\begin{array}{c}\text { NUMBER } \\
\text { ATTEMPTS }\end{array}$ & $\begin{array}{c}\text { YOUNG } \\
\text { BANDED }\end{array}$ & \\
\hline \multicolumn{6}{|l|}{ Nests not monitored } \\
\hline Dead trees unsafe to climb & 73 & 0 & 14 & 0 & 87 \\
\hline \multicolumn{6}{|l|}{ Nests monitored } \\
\hline Safe trees, failed attempts & 77 & 0 & 34 & 0 & 111 \\
\hline Platforms, failed attempts & 3 & 0 & 23 & 0 & 26 \\
\hline Safe trees, successful & 67 & 134 & 27 & 52 & 94 \\
\hline Platforms, successful & 7 & 18 & 37 & 73 & 44 \\
\hline $\begin{array}{l}\text { Total nests in trees } \\
\text { Total nests on platforms }\end{array}$ & $\begin{array}{r}144 \\
10\end{array}$ & & $\begin{array}{l}61 \\
60\end{array}$ & & \\
\hline Total attempts monitored & 154 & 152 & 121 & 125 & 275 \\
\hline
\end{tabular}






Figure 3. Photograph of Osprey nest platform near Loon Lake, Saskatchewan.

continent, the prospect of a pair of Ospreys fledging one or more young was appreciably improved when artificial nest structures were used. The overall breeding success improved from $45.9 \%$ in natural trees (94 of 205 attempts) to $62.9 \%$ on man-made platforms (44 of 70 attempts). This difference is statistically significant $\left(\chi^{2}=6.035, P<0.025\right)$.

We learned from experience. Our first ten platforms received only $33 \%$ occupancy, whereas the last ten platforms have achieved $95 \%$ occupancy ( 22 platform-years with success, 16 platform-years with failures and only $2 \mathrm{yr}$ where a platform was not used; Table 2, Fig. 3). For these reasons we have chosen to emphasize the difference between the data sets from 1978 through 1985 and the recent years, 198691.

An overall average of 1.3 young were fledged per platform breeding attempt (91/70) as compared to 0.9 young fledged per tree nest breeding attempt $(186 / 205)$. However, if one excludes failed attempts, the two nest site categories are not significantly different: 2.1 per young per successful platform nest
$(91 / 44)$ and 2.0 per young per successful tree nest (186/94).

At this latitude $\left(54^{\circ} \mathrm{N}\right)$, we have not yet observed building of a new nest and successful production of young in the same year. Though building of a new nest was sometimes initiated after the original nest blew down, completion was always too late for young to be produced that season. Therefore, a nest platform has the potential to save $2 \mathrm{yr}$ of production: the year the nest would have blown down and the year a new nest would be built.

Since 1986 we have left few unsafe nest trees standing and have replaced them with platforms. While 67 of 74 successful breeding attempts in the first $11 \mathrm{yr}$ were in trees and only 7 on platforms, in the last 6 yr over half of the successful nest attempts, 37 of the last 64, have been on platforms.

Year. Poor overall success may be related in part to inclement weather. In 1990, the year of lowest production, after a storm on 3 July with moderate winds, cool temperatures $\left(7^{\circ} \mathrm{C}\right)$, and steady rain $(43$ $\mathrm{mm}$ ), there was marked brood reduction by $14-15$ 
Table 2. Osprey nest platforms built at Loon Lake, 1978-90, and used through 1991.

\begin{tabular}{|c|c|c|c|c|c|}
\hline \multicolumn{2}{|c|}{ YEAR BUILT } & \multirow{2}{*}{$\begin{array}{c}\begin{array}{c}\text { YEARS } \\
\text { WITH } \\
\text { SUCCESS }\end{array} \\
1\end{array}$} & \multirow{2}{*}{$\begin{array}{c}\begin{array}{c}\text { YEARS } \\
\text { WITH } \\
\text { FAILURE }\end{array} \\
5\end{array}$} & \multirow{2}{*}{$\begin{array}{c}\begin{array}{c}\text { Years } \\
\text { No'T UsED }\end{array} \\
8\end{array}$} & \multirow[t]{2}{*}{ COMMENTS } \\
\hline 1978 & $\# 1$ & & & & \\
\hline & $\# 2$ & 0 & 0 & 14 & \\
\hline & \#3 & 0 & 0 & 14 & \\
\hline 1983 & \#4 & 4 & 2 & 2 & Ospreys built $2 \times$ in nearby dead trees \\
\hline & \#5 & 0 & 0 & 9 & \\
\hline & \#6 & 0 & 0 & 9 & \\
\hline 1984 & \#7 & 3 & 0 & 5 & \\
\hline & $\# 8$ & 4 & 0 & 4 & \\
\hline 1985 & \#9 & 6 & 1 & 0 & Lag bolts broke 1991 \\
\hline & \#10 & 4 & 2 & 1 & $\begin{array}{l}\text { Lag bolts replaced spring } 1989 \\
\text { Ospreys built in dead tree } 1991\end{array}$ \\
\hline First & ten total & 22 & 10 & 66 & $\begin{array}{l}\text { First ten platforms } \\
32 / 98 \text { or } 33 \% \text { usage }\end{array}$ \\
\hline 1986 & $\# 11$ & 3 & 3 & 0 & \\
\hline & \#12 & 2 & 3 & 1 & \\
\hline 1987 & \#13 & 3 & 2 & 0 & \\
\hline & \#14 & 4 & 1 & 0 & One with addled eggs 1990 \\
\hline 1988 & \#15 & 2 & 1 & 1 & \\
\hline & \#16 & 3 & 1 & 0 & Lag bolts broke 1990 \\
\hline 1989 & $\# 17$ & 0 & 3 & 0 & One with addled eggs 1991 \\
\hline & \#18 & 2 & 1 & 0 & \\
\hline 1990 & \#19 & 2 & 0 & 0 & Platform on 1st windmill frame \\
\hline & $\# 20$ & 1 & 1 & 0 & Headless yg in nest 1990 \\
\hline Secon & ad ten total & 22 & 16 & 2 & $\begin{array}{l}\text { Last ten platforms since } 1986 \\
38 / 40 \text { or } 95 \% \text { usage }\end{array}$ \\
\hline Total & & 44 & 26 & 68 & \\
\hline
\end{tabular}

July, possibly as a result of exposure. With favorable weather in 1991, more young Ospreys were produced than ever before, even though there were fewer nesting attempts. We have not discerned any relation with food supply as measured by human fishing success on adjacent lakes.

Trapping of Adults with Noose Carpets. Since ours is the most discrete population recorded in Saskatchewan, we hoped that trapping of adults on the nest, in 1988-90, would result in recapture of Ospreys banded in the area as nestlings.

The one adult that had been raised and later was trapped locally was 608-09790, banded as a nestling on 18 July 1976 at Branch Lake. This bird was trapped as an adult female on her nest on 3 June 1989 at Makwa Lake and again at the same nest on 2 June 1990. She was incubating three eggs each time, $6 \mathrm{~km}$ south and $18 \mathrm{~km}$ east of where she had been banded as a nestling.
Re-trapped banded adults were as follows: in 1989, three females banded as adults on nest in 1988; in 1990 , two females banded as adults in 1988, two females banded as adults in 1989 and one male banded as an adult in 1989. Only one female had shifted to a different nest site.

We watched carefully for any adverse effects of trapping but observed none in the first 2 yr. In 1988, from 11 adult capture attempts we trapped 7 adults at six platforms and one tree. The tree nest fell down, but five of six platforms were successful and fledged 12 young. In 1989, 13 of 15 attempts were successful; we caught 13 adults, 9 of which were unbanded, at 11 platforms (both adults at one) and 1 tree; 8 of the 11 platforms were successful and fledged 18 young and the tree nest fledged 1 young.

In 1990 , in 12 of 14 attempts we caught 12 adults (6 unbanded) at 11 platforms; 7 platforms failed and the other 4 raised only six young. Although we were 
concerned that our trapping might have contributed to this poor result, it was more likely a part of the generalized poor productivity that year, for at the seven tree nests, where no trapping of adults had been attempted, five failed and the two successful tree nests fledged only one young each.

A single banded Osprey among 23 adults trapped on the nest (7 new adults nest-trapped in 1988, 9 new adults in 1989 and 6 new adults in 1990) may be an indication that there is a wider dispersal of Ospreys in Saskatchewan than among eastern populations (cf., Postupalsky 1989).

In case our trapping intervention had contributed in part to the decreased nest success in 1990, we avoided trapping of adults in 1991. We plan to resume trapping adults in odd-numbered years only.

Migration. From 277 nestling Loon Lake Ospreys and 14 from seven other Saskatchewan lakes, 12 recoveries to date include 2 from Colombia and 1 each from Ecuador, Panama, Costa Rica, Veracruz, Louisiana and New Mexico. As yet there have been no distant recoveries from the 22 adults banded (Ewins and Houston in press).

"Leapfrogging," whereby the most northerly birds winter farther south, appears to occur in western North America, though the sample size is yet small. Ospreys from Saskatchewan and British Columbia winter in southern Central America and in northwestern South America as far south as the equator, farther south than the main wintering area (Mexico) of western United States birds (Poole and Agler 1987).

\section{ACKNOWLEDGMENTS}

We wish to thank those who have helped on two or more weekends of platform building or banding: Marc
Bechard, Bert Dalziel, Bruce Donovan, Dick Ehman, Martin Gerard, John Hanbidge, Kim Hruska, Alvin Lasich (deceased), Nigel Mathews, David Miller, Ron Marlatte, Tim Molnar, David Surkan, Rob Tether, Dylan von Kuster, and Kelly Wylie. Constructive criticism was provided by Marc Bechard, Mitchell Byrd and Peter Ewins.

\section{Literature Gited}

Ewins, P.J. AND C.S. Houston. 1992. Recovery patterns of Ospreys, Pandion haliaetus, banded in Canada up to 1989. Can. Field-Nat. in press.

Houston, C.S., J.M. Gerrard, D.W.A. Whitfield, H.A. Stelfox and W.J. Maher. 1977. Osprey nesting records in Saskatchewan. Blue Jay 35:38-41.

Poole, A.F. 1989. A natural and unnatural history of ospreys. Cambridge University Press, Cambridge, U.K. - AND B. AgLer. 1987. Recoveries of ospreys banded in the United States, 1914-1984. J. Wildl. Manage. 51:148-155.

Postupalsky, S. 1989. Osprey. Pages 297-313 in I. Newton [ED.], Lifetime reproduction in birds. Academic Press, London, U.K.

- AND S.M. STACkPOLE. 1974. Artificial nesting platforms for ospreys in Michigan. Pages 105-117 in F.N. Hamerstrom, Jr., B.E. Harrell and R.R. Olendorff [EDS.], Management of raptors. Raptor Research Report No. 2, Raptor Research Foundation, Inc., Hastings, MN.

ScOTT, F. AND C.S. Houston. 1983. Osprey nesting success in west-central Saskatchewan. Blue Jay 41:2732.

- AND - 1985. Success of osprey nest platforms near Loon Lake, Saskatchewan. Blue Jay 43: 238-242.

AND D.L. SURKan. 1976. An unsuspected osprey concentration in west-central Saskatchewan. Blue Jay 34:99-101.

Received 24 April 1992; accepted 23 June 1992

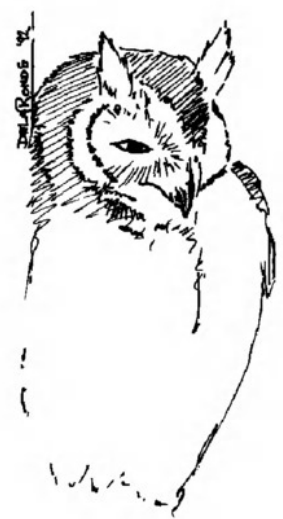




\section{$2 \mathrm{BHL}$ Biodiversity Heritage Library}

Houston, C Stuart and Scott, Frank J. 1992. "THE EFFECT OF MAN-MADE PLATFORMS ON OSPREY REPRODUCTION AT LOON LAKE, SASKATCHEWAN." The journal of raptor research 26(3), 152-158.

View This Item Online: https://www.biodiversitylibrary.org/item/209280

Permalink: https://www.biodiversitylibrary.org/partpdf/227368

\section{Holding Institution}

Raptor Research Foundation

\section{Sponsored by}

IMLS LG-70-15-0138-15

\section{Copyright \& Reuse}

Copyright Status: In copyright. Digitized with the permission of the rights holder.

Rights Holder: Raptor Research Foundation

License: http://creativecommons.org/licenses/by-nc-sa/4.0/

Rights: https://biodiversitylibrary.org/permissions

This document was created from content at the Biodiversity Heritage Library, the world's largest open access digital library for biodiversity literature and archives. Visit BHL at https://www.biodiversitylibrary.org. 